\title{
The potential role of respiratory motion management and image guidance in the reduction of severe toxicities following stereotactic ablative radiation therapy for patients with centrally located early stage non-small cell lung cancer or lung metastases
}

\author{
Alexander $\mathrm{Chi}^{1}{ }^{*}, \mathrm{Nam}$ Phong Nguyen ${ }^{2}$ and Ritsuko Komaki ${ }^{3}$ \\ ${ }^{1}$ Department of Radiation Oncology, Mary Babb Randolph Cancer Center of West Virginia University, Morgantown, WV, USA \\ 2 International Geriatric Radiotherapy Group, Tucson, AZ, USA \\ ${ }^{3}$ Department of Radiation Oncology, University of Texas MD Anderson Cancer Center, Houston, TX, USA
}

\section{Edited by:}

Ulf Lennart Karlsson, Marshfield

Clinic, USA

\section{Reviewed by:}

Terence Tai Weng Sio, Mayo Clinic, USA

Yidong Yang, University of Miami Miller School of Medicine, USA

\section{${ }^{*}$ Correspondence:}

Alexander Chi, Mary Babb Randolph Cancer Center of West Virginia

University, PO Box 9234, 1 Medical

Center Drive, Morgantown, WV

26505, USA

e-mail: achiaz2010@gmail.com
Image guidance allows delivery of very high doses of radiation over a few fractions, known as stereotactic ablative radiotherapy (SABR). This treatment is associated with excellent outcome for early stage non-small cell lung cancer and metastases to the lungs. In the delivery of SABR, central location constantly poses a challenge due to the difficulty of adequately sparing critical thoracic structures that are immediately adjacent to the tumor if an ablative dose of radiation is to be delivered to the tumor target. As of current, various respiratory motion management and image guidance strategies can be used to ensure accurate tumor target localization prior and/or during daily treatment, which allows for maximal and safe reduction of set up margins. The incorporation of both may lead to the most optimal normal tissue sparing and the most accurate SABR delivery. Here, the clinical outcome, treatment related toxicities, and the pertinent respiratory motion management/image guidance strategies reported in the current literature on SABR for central lung tumors are reviewed.

Keywords: stereotactic ablative radiotherapy, SABR, central location, non-small cell lung cancer, metastases

\section{INTRODUCTION}

In the past, thoracic radiotherapy has constantly been limited by toxicity to the normal tissue, such as the lungs and the esophagus, which hinders dose escalation to the gross disease to a desired therapeutic level (1-3). This is mainly due to the utilization of large planning target volume (PTV) margins to compensate uncertainties from respiratory motion and/or in daily patient set up $(4,5)$. In recent years, advances in imaging technology have enabled us to not only more accurately delineate the gross tumor volume (GTV) and the clinical target volume (CTV), but also given us more information on the location of tumor in relation to critical structures throughout the entire respiratory cycle $(1,2,4-7)$. Thus, a PTV margin reduction is possible through accurate delineation of the internal target volume (ITV), which allows for dose escalation to the gross tumor. Tumor localization can be further verified with additional in-room imaging prior to daily treatment to ensure accurate radiation delivery (8). With image-guided radiotherapy (IGRT), ablative doses of radiation can be delivered to treat early stage non-small cell lung (T1-3, N0, M0) or lung metastases, a technique known as stereotactic ablative radiotherapy (SABR) or stereotactic body radiation therapy (SBRT), with excellent clinical outcome consistently observed (9), while local control of over $80 \%$ at 3 years have been observed following SABR for oligometastases to the lungs $(10,11)$.
Despite the rapid clinical adaptation of SABR worldwide, the feasibility of SABR in the treatment of centrally located lung lesions continues to be controversial. The central location is defined as a region that is within $2 \mathrm{~cm}$ of the proximal bronchial tree (12). In a phase II prospective study on SABR for T1-2, N0, M0 NSCLC, 60-66 Gy was delivered in three fractions to the tumor target, and the 2-year freedom from severe toxicity was much higher for peripheral lesions when compared to that for central lesions ( 83 vs. $54 \%$ ) (13). A total of 12 Grade 3-5 treatment related toxicities were reported at 4 years in this study of 70 patients (14), 5 of which were Grade 5 toxicities. These consisted of pneumonia (three cases), hemoptysis (one case), and respiratory failure (one case). On the contrary, excellent clinical outcome with reasonable toxicity profile has also been reported by others who used dose fractionation regimens with lower fractional dose and increased number of fractions (9). However, treatment related lethal toxicity following SABR for central lung lesions, such as hemoptysis from SABR-related necrosis in the major airway, is still observed when the organ at risk (OAR) was in the high dose volume even when moderate fractionation schedules have been used (15). Therefore, not only lower fractional dose with increased number of fractions is necessary, but geometric accuracy and avoidance of immediately adjacent OARs from being included in the high dose volume are also critical in achieving optimal target volume dose coverage 
and OAR sparing in the treatment of central lung lesions with SABR (16). These objectives are further complicated by breathing motion, which leads to variation in tumor location relative to adjacent critical organs throughout the entire respiratory cycle. As a result, a high level of image guidance is required to ensure accurate delivery of ablative doses to the tumor target with the smallest treatment margin possible for optimal OAR sparing. In this situation, a sharp dose gradient at the edge of the PTV to spare the immediately adjacent normal organs from receiving an ablative dose of radiation is also strongly desired. In the following sections, the key components of image-guided SABR will be discussed in relation to clinical experience on SABR for central lung lesions. Furthermore, how currently available respiratory motion management and image guidance techniques are used for safe delivery of SABR for central lung lesions, and how to select patients for SABR in this setting will be explored.

\section{CLINICAL EXPERIENCE WITH SABR FOR CENTRAL LUNG TUMORS}

The clinical experience in delivering SABR for central lung tumors has been reported together with that for peripheral lung tumors in multiple studies (12-14, 17-29). In general, no statistically significant difference in the clinical outcome based on tumor location was observed following SABR for early stage NSCLC $(14,18,21$, $24,25,27-30)$. As shown previously, the biologically effective dose (BED) appears to be a direct predictor of local control following SABR with increased failures observed when a lower BED is delivered to the tumor target irrespective of tumor location $(12,23,26)$. In recent years, a number of studies have reported the clinical experience with SABR for central lung lesions alone (30-36). As shown in Table 1, the local control and overall survival following SABR for centrally located early stage NSCLC appear to be very similar to what has been observed following SABR for early stage NSCLC in general (12). Again, BED appears to be a significant predictor of local control favoring a BED of $\geq 100 \mathrm{~Gy}_{10}$ [Gy calculated using an $\alpha / \beta=10 \mathrm{~Gy}, \mathrm{BED}=$ total dose $\times(1+$ fractional dose $/(\alpha / \beta))]$ to the tumor target (37). These findings corroborate with what have been observed in the studies including both peripheral and central lung tumors as mentioned above. Also suggested by studies listed in Table 1, poorer clinical outcome may be observed in advanced stage/recurrent NSCLC or metastases to the lungs when compared with that for early stage NSCLC.

Severe toxicities and deaths following SABR for centrally located lung lesions have been reported in many studies, which brought great concern regarding the feasibility of SABR for centrally located lung tumors $(13,14,17-21,30,32-35)$. In these studies, large fractional dose, and/or failure to exclude OARs immediately adjacent to the tumor target from the high dose volume were frequently observed. Both often associated with deaths due to pulmonary injury or bleeding in areas of necrosis in the immediately adjacent organs, such as the esophagus, or the major airways (Tables 2 and $\mathbf{3}$ ). As shown in the Indiana phase II study, which included both peripherally and centrally located NSCLC (T1-2, N0, M0), 8 patients with Grade 3-4 toxicities, and 6 SABRrelated deaths were identified among 70 patients after a median follow up of 17.5 months when $60-66$ Gy was delivered in three fractions (13). The toxicities were mostly cardio-pulmonary in nature. The rate of severe toxicity (Grade 3-5, CTCAE version 2.0.) significantly correlated with tumor location initially with an 11 -fold increase in the risk of severe toxicity associated with central location (13). It suggests that centrally located lesions need to be treated differently even when this correlation lost statistical significance after a median follow up of 50.2 months due mostly to the small number of patients included. Death following treatment of central lung lesions with much lower dose per fraction was initially reported by Onimaru et al. (17). This occurred when the esophagus was not excluded from the high dose volume. It ultimately resulted in death due to hemoptysis as a result of an unhealing esophageal ulcer 5 months after SABR. A hot spot above the prescribed dose on the esophagus was later discovered, which may have contributed to esophageal ulceration.

Treatment related toxicities causing death have also been observed in other studies (18-21). As shown in Table 2, death due to bleeding/hemoptysis has been frequently observed following primary or repeat treatments of central lung lesions with SABR. Bronchial strictures and tissue necrosis have also been frequently encountered following SABR for lesions that were adjacent to or within the airways $(18,19)$. In one study, partial or complete bronchial strictures have been observed in $8 / 9$ patients with centrally located stage I NSCLC after doses from 40-48 Gy/4 to $60 \mathrm{~Gy} / 3$ fractions were delivered (18). In their study, severe pulmonary toxicities associated with partial bronchial stricture were observed after $40 \mathrm{~Gy} / 4$ fractions were delivered. In a different study, death due to hemoptysis related to bronchial stenosis was observed after a peri-bronchial lesion was treated with $60 \mathrm{~Gy} / 4$ fractions (21). These findings demonstrate the risk for severe toxicity due to SABR-related bronchial stricture, which should be avoided whenever possible.

In studies that evaluated SABR for central lesions only (3036), the incidence of severe toxicities was low among the patients reported. This may be related to lower fractional dose in the dose fractionation schedules used, patient selection, availability of cutting-edge technology for image guidance, and respiratory motion control, as well as many other factors. Among these studies, 9 deaths were reported following SABR in a total of 287 patients (Table 3). Again, bleeding due to tissue necrosis of the immediately adjacent OARs appears to be a common cause of death. Five deaths occurred after multiple courses of radiotherapy to single or multiple peri-bronchial lesions $(33,35)$, while one death occurred after SABR was delivered to an endobronchial lesion (34). One potential treatment related death due to a cardiac cause occurred in a patient with underlying cardiac conditions for whom the PTV and the heart overlapped (30). One death due to bronchial necrosis related hemorrhage occurred 10.5 months after SABR to a $5.7-\mathrm{cm}$ metastasis abutting the left mainstem bronchus (32). The area of bronchial necrosis was retrospectively found to have received a maximum dose above the dose prescribed.

Stereotactic ablative radiotherapy for central lung tumors has been shown to be feasible without any treatment related severe toxicities by many as well (22-29). No fractional dose of over 12.5 Gy was used among them, which further supports the need to lower the fractional dose when treating centrally located lesions to avoid severe late toxicities (Table 4). However, SABR may not be the best treatment option for endobronchial lesions as it was 


\begin{tabular}{|c|c|c|c|c|c|c|c|c|c|}
\hline Reference & $\begin{array}{c}\text { No. of } \\
\text { patients }\end{array}$ & $\begin{array}{l}\text { Median } \\
\text { age }\end{array}$ & Histology & $\begin{array}{c}\text { Median FU } \\
\text { (months) }\end{array}$ & Dose & Local control & DFS/PFS/CSS & os & Severe toxicities \\
\hline $\begin{array}{l}\text { Haasbeek } \\
\text { et al. (30) }\end{array}$ & 63 & $74(47-87)$ & $\begin{array}{l}\text { NSCLC:T1-3, NO, } \\
\text { MO }\end{array}$ & 35 & $60 \mathrm{~Gy} / 8 \mathrm{frx}$ & 5 years: $92.6 \%$ & 5 years-DFS: $71 \%$ & 5 years: $49.5 \%$ & $\begin{array}{l}\text { Acute: } 1 \text { Grade } 3 \text { chest wall } \\
\text { pain } \\
\text { Late: } 2 \text { Grade } 3 \text { dyspnea } \\
1 \text { Grade } 3 \text { chest wall pain } \\
1 \text { Grade } 3 \text { rib fracture } \\
2 / 9 \text { Deaths potentially } \\
\text { related to SABR }\end{array}$ \\
\hline $\begin{array}{l}\text { Nuyttens et al. } \\
\text { (31) }\end{array}$ & 56 & 73 (34-88) & $\begin{array}{l}\text { NSCLC: } 69.6 \% \\
\text { metastases: } 30.4 \%\end{array}$ & 23 & $\begin{array}{l}45-60 \mathrm{~Gy} / 5 \mathrm{frx} \\
48 \mathrm{~Gy} / 6 \mathrm{frx}\end{array}$ & $\begin{array}{l}2 \text { years: } 76 \% \text { (early } \\
\text { stage NSCLC: } 85 \% \text { ) }\end{array}$ & $\begin{array}{l}3 \text { years-CSS (early } \\
\text { stage NSCLC): } 80 \%\end{array}$ & $\begin{array}{l}2 \text { years: } 60 \% \text { (early } \\
\text { stage NSCLC: } 53 \% \text { ) }\end{array}$ & $\begin{array}{l}\text { Acute: } 4 \text { Grade } 3 \\
\text { pneumonitis } \\
\text { Late: } 6 \text { Grade } 3 \text { pneumonitis }\end{array}$ \\
\hline $\begin{array}{l}\text { Rowe et al. } \\
\text { (32) }\end{array}$ & 47 & $72(41-90)$ & $\begin{array}{l}\text { NSCLC: } 59 \% \\
\text { metastases: } 41 \%\end{array}$ & 11.3 & 50 Gy/4 frx (57\%) & $\begin{array}{l}\text { Two local failures } \\
\text { observed }\end{array}$ & & & $\begin{array}{l}4 \text { Grade } 3 \text { dyspnea within } \\
2-4 \text { months after SABR } \\
\text { One SABR-related death }\end{array}$ \\
\hline $\begin{array}{l}\text { Oshiro et al. } \\
\text { (33) }\end{array}$ & 21 & $71(35-89)$ & $\begin{array}{l}\text { Recurrent/metastatic } \\
\text { NSCLC: } 95 \% \\
\text { Stage IA: } 1 \\
\text { Stage IV: } 8 \\
\text { Recurrent } \\
\text { rl: } 4 \\
\text { IIIA: } 1\end{array}$ & 19.8 & $\begin{array}{l}25-35 \text { Gy/1 frx } \\
40-48 \text { Gy/4 frx } \\
40-50 \text { Gy/5 frx } \\
48 \text { Gy/8 frx } \\
50-60 \text { Gy/10 frx } \\
39 \text { Gy/3 frx }\end{array}$ & 2 years: $59.6 \%$ & 2 years-PFS: $23.8 \%$ & 2 years-OS: $62.2 \%$ & $\begin{array}{l}\text { Acute: none } \\
\text { Late: } 1 \text { Grade } 3 \text { productive } \\
\text { cough due to bronchial } \\
\text { stenosis requiring dilatation } \\
1 \text { year after treatment } \\
1 \text { Grade } 3 \text { dyspnea } \\
18 \text { months after SABR, } \\
\text { which was preceded by } \\
\text { three courses of RT to } \\
\text { bilateral tumors } \\
\text { One SABR-related death }\end{array}$ \\
\hline $\begin{array}{l}\text { Unger et al. } \\
\text { (34) }\end{array}$ & 20 & $\sim(23-82)$ & $\begin{array}{l}\text { Hilar lesions } \\
\text { abutting or invading } \\
\text { the mainstem } \\
\text { bronchus. } \\
\text { Metastases: } 85 \%\end{array}$ & 10 & $30-40 \mathrm{~Gy} / 5 \mathrm{frx}$ & 1 year: 63\% & & 1 year: $54 \%$ & $\begin{array}{l}\text { Acute: } 1 \text { Grade } 3 \text { radiation } \\
\text { pneumonitis } 8 \text { months after } \\
\text { SABR } \\
\text { One SABR-related death }\end{array}$ \\
\hline
\end{tabular}




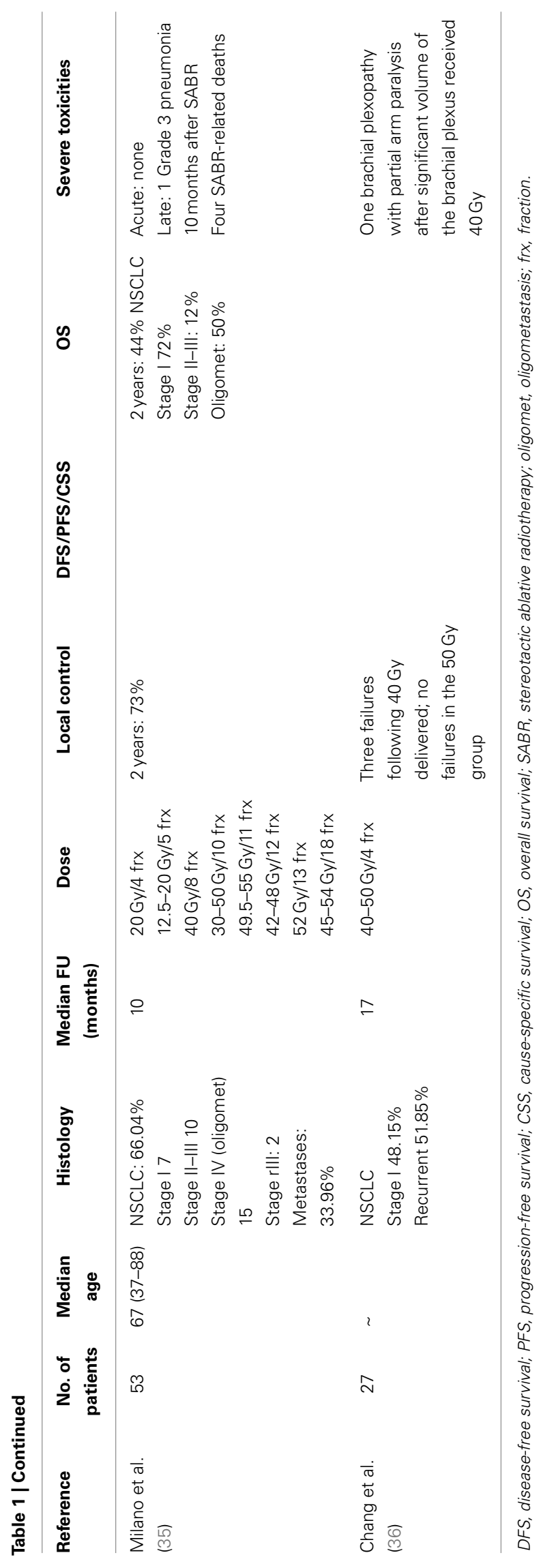

frequently found to result in bronchial necrosis related complications, causing death $(18,19,34)$. In addition, re-irradiating central lung lesions with hypofractionated dose fractionation regimens needs to be considered very carefully given the already increased risk of normal tissue injury from prior treatment $(20,33,35)$.

As suggested by the clinical experience summarized above, the following are of pertinent importance in minimizing the risk of severe toxicities following SABR for central lung tumors: the use of dose fractionation schedules with relatively lower fractional dose while increasing the number of fractions accordingly to maintain an adequate BED; carefully respecting the dose constraints for the immediately adjacent OARs during treatment planning; and validation of accurate tumor localization through daily image guidance to ensure that the immediately adjacent structures are kept outside of the high dose region in the context of respiratory motion. Furthermore, sharp dose gradient at the PTV's edge through intensity modulation is strongly desired to optimize conformal avoidance of the immediately adjacent OARs when treating central lesions with SABR (12). This makes image guidance even more critical in the delivery of daily treatments. In the following sections, the current available respiratory motion management/image guidance techniques that can be used to optimize the safe and accurate delivery of SABR to treat central lung lesions in the context of the clinical studies described above will be further described and assessed.

\section{RESPIRATORY MOTION MANAGEMENT IN LUNG SABR}

Patient immobilization, respiratory motion management, and appropriate image guidance are closely integrated in thoracic IGRT. Multiple image guidance techniques are currently in use to ensure accurate tumor localization during lung SABR and these are closely related to the strategy for respiratory motion management that is used in conjunction with them. Tumor motion due to respiration in various locations of the lungs has been previously described by Seppenwoolde et al. (4). The greatest motion was observed in lower lobe tumors that were not attached to rigid structures in the cranio-caudal direction $(12 \pm 2 \mathrm{~mm})$, while the lateral motion appears to be much less $(2 \pm 1 \mathrm{~mm})$. The tumors were found to be more stable and spending more time in the expiratory phase of respiration. In addition, hysteresis of $1-5 \mathrm{~mm}$ has been observed commonly (4).

A more detailed description of respiratory motion can be found in a report by AAPM task group 76 (38), which further illustrates that patients' breathing patterns are irregular, and are highly variable in magnitude, and period. They not only vary intraand inter-fractionally, but also vary between different patients. As shown by Wulf et al., a uniform ITV margin of $5 \mathrm{~mm}$ in transverse and $10 \mathrm{~mm}$ cranio-caudally still led to partial misses of tumor targets in $12-16 \%$ of the patients even in the setting of stereotactic body frame usage (39). Therefore, individually accounting for respiratory motion with patients breathing in a repeatable fashion is essential for the most accurate and precise capturing of internal organ motion. Furthermore, tumor location needs to be verified under daily image guidance to ensure appropriate dose distribution during actual treatment to justify small PTV margins for the most optimal OAR sparing. 
Table 2 | Deaths following SABR for central lung tumors in studies including both peripheral and central lesions.

\begin{tabular}{|c|c|c|c|c|c|}
\hline Reference & $\begin{array}{l}\text { Median FU } \\
\text { (months) }\end{array}$ & $\begin{array}{l}\text { No of central } \\
\text { lesions/study }\end{array}$ & $\begin{array}{l}\text { Lesions associated } \\
\text { with death }\end{array}$ & $\begin{array}{l}\text { Dose schedule } \\
\text { associated with death }\end{array}$ & $\begin{array}{l}\text { Cause of death/time } \\
\text { of death }\end{array}$ \\
\hline Fakiris et al. (14) & 50.2 & 22 & $\begin{array}{l}\text { A pericarinal and a } \\
\text { pericardial NSCLC }\end{array}$ & 60-66 Gy/3 frx & $\begin{array}{l}\text { Hemoptysis ( } 19.5 \text { months after } \\
\text { SABR) and pericardial effusion }\end{array}$ \\
\hline Onimaru et al. (17) & 18 & 9 & $\begin{array}{l}\text { A 3.5-cm metastasis from } \\
\text { melanoma posterior to the R } \\
\text { mainstem bronchus } \\
\text { Esophageal dose } \\
\text { parameters } \\
\text { Maximum dose: } 50.5 \mathrm{~Gy} \\
\text { Mean dose: } 10.6 \mathrm{~Gy} \\
1 \text { cc dose: } 42.5 \mathrm{~Gy}\end{array}$ & $48 \mathrm{~Gy} / 8 \mathrm{frx}$ & $\begin{array}{l}\text { Bleeding from an unhealing } \\
\text { esophageal ulcer } 5 \text { months after } \\
\text { SABR }\end{array}$ \\
\hline Song et al. (18) & 26.5 & 9 & $\begin{array}{l}\text { Endobronchial NSCLC in the } \\
\text { mainstem bronchus }\end{array}$ & $48 \mathrm{~Gy} / 4 \mathrm{frx}$ & $\begin{array}{l}\text { Hemoptysis, aspiration, and } \\
\text { pneumonia from treatment induced } \\
\text { complete bronchial stricture } \\
13 \text { months after SABR }\end{array}$ \\
\hline Stauder et al. (19) & 15.8 & 47 & $\begin{array}{l}\text { A recurrent NSCLC that is } \\
\text { obstructing the } L \text { mainstem } \\
\text { bronchus (pneumonectomy } \\
\text { on the contralateral side } \\
17 \text { years ago) }\end{array}$ & $48 \mathrm{~Gy} / 4 \mathrm{frx}$ & $\begin{array}{l}\text { Pulmonary failure caused by } \\
\text { progressive bronchial obstruction } \\
\text { due to tumor necrosis } 7.5 \text { months } \\
\text { after SABR }\end{array}$ \\
\hline Peulen et al. (20) & 12 & 11 & $\begin{array}{l}\text { Bilateral hilar metastases } \\
\text { from RCC, then R hilar } \\
\text { recurrence } 3 \text { years later } \\
\text { L hilar NSCLC encasing a } \\
\text { lobar bronchus } \\
\text { Carinal recurrence from } \\
\text { esophageal cancer }\end{array}$ & $\begin{array}{l}40 \mathrm{~Gy} / 4 \mathrm{frx} \text {, then } 40 \mathrm{~Gy} / 5 \\
\mathrm{frx} \\
40 \mathrm{~Gy} / 4 \mathrm{frx} \text { to the primary } \\
\text { disease followed by } \\
33 \mathrm{~Gy} / 3 \mathrm{frx} 13 \text { months later } \\
40 \mathrm{~Gy} / 5 \mathrm{frx} \text { following } \\
\text { chemotherapy followed by } \\
40 \mathrm{~Gy} / 5 \mathrm{frx} 29 \text { months later }\end{array}$ & $\begin{array}{l}\text { Hemoptysis } 10 \text { months after second } \\
\text { course of SABR } \\
\text { Hemoptysis/hemorrhage } 6 \text { weeks } \\
\text { after second course of SABR } \\
\text { A fistula between G-tube and } \\
\text { trachea developed } 10 \text { months after } \\
\text { second course of SABR; local } \\
\text { progression } 13 \text { months after second } \\
\text { SABR was treated with } 40 \text { Gy/5 frx, } \\
\text { then again } 42 \text { Gy/7 frx } 8 \text { months } \\
\text { later; The patient was found to have } \\
\text { developed SVC syndrome due to } \\
\text { severe RT induced fibrosis } 7 \text { months } \\
\text { after third course of SABR and died } \\
\text { of an MI during stent placement }\end{array}$ \\
\hline Bral et al. (21) & 16 & 17 & $\begin{array}{l}\text { Peri-bronchial early stage } \\
\text { NSCLC }\end{array}$ & $60 \mathrm{~Gy} / 4 \mathrm{frx}$ & $\begin{array}{l}\text { Hemoptysis related to Grade } 3 \\
\text { dyspnea due to bronchial stenosis. } \\
\text { The patient died during stenting }\end{array}$ \\
\hline
\end{tabular}

Frx, fractions; RCC, renal cell carcinoma.

Respiratory motion management strategies currently in use are usually separated into five different categories: motion encompassing, respiratory gating, breath hold, forced shallow breathing with abdominal compression and breath-synchronized, or real time tumor tracking techniques (38). Among them, motion encompassing techniques to estimate the range of tumor motion have been most commonly used in the treatment of central lesions with SABR (Table 5). These include slow CT scanning, ITV generation with inhalation and exhalation breath hold CTs combined with free-breathing CT, and $4 \mathrm{D}$ or respiration corrected CT. A slow CT is generated with a speed that would allow multiple respiratory cycles to be captured per slice to generate a tumor encompassing volume, which depicts tumor location throughout the entire respiratory cycle. This approach is limited by the lack of contrast between tumor from normal tissue when it is located in the vicinity of the mediastinum, the diaphragm, or the chest wall as a result of respiration related blurring. Alternatively, FDG PET registered to the planning CT has been used by some to aid target volume delineation due to the enhanced resolution of tumor in areas of soft tissue associated with image registration; and the 
Table 3 | Deaths reported in studies on SABR for central lung tumors only.

\begin{tabular}{|c|c|c|c|c|}
\hline Reference & Dose prescribed & $\begin{array}{l}\text { Immediately } \\
\text { adjacent organs }\end{array}$ & $\begin{array}{l}\text { Dose to critical } \\
\text { organs }\end{array}$ & $\begin{array}{l}\text { Cause of death/time } \\
\text { of death }\end{array}$ \\
\hline Haasbeek et al. (30) & $60 \mathrm{~Gy} / 8 \mathrm{frx}$ & $\begin{array}{l}\text { Pericardium overlapping } \\
\text { the target volume } \\
\mathrm{R} \text { hilum }\end{array}$ & Unknown & $\begin{array}{l}\text { Cardiac event } 2.5 \text { years after } \\
\text { SABR } \\
\text { Respiratory failure }\end{array}$ \\
\hline Rowe et al. (32) & $\begin{array}{l}50 \mathrm{~Gy} / 4 \text { frx to a metastasis from } \\
\text { melanoma }\end{array}$ & L mainstem bronchus & $\begin{array}{l}\text { Airway point dose: } 54.2 \mathrm{~Gy} \\
\text { Airway }{ }_{5 \mathrm{cc}} \text { dose: } 12.7 \mathrm{~Gy} \\
\text { (overall: } 14.7 \mathrm{~Gy} \text { ) }\end{array}$ & $\begin{array}{l}\text { Hemorrhage with bronchial } \\
\text { necrosis in the region of the } \\
\text { maximum point dose } \\
10.5 \text { months after SABR }\end{array}$ \\
\hline Oshiro et al. (33) & $25 \mathrm{~Gy} / 1 \mathrm{fr} \mathrm{x}^{\mathrm{a}}$ & Hilum of unknown side & Unknown & $\begin{array}{l}\text { Hemoptysis } 18 \text { months after } \\
\text { SABR }\end{array}$ \\
\hline Unger et al. (34) & $\begin{array}{l}\text { 30-40 Gy/5 frx to an } \\
\text { endobronchial lesion from } \\
\text { mesothelioma }\end{array}$ & $\begin{array}{l}\text { Unknown mainstem } \\
\text { bronchus }\end{array}$ & $\begin{array}{l}\text { Maximum point dose: } \\
49 \mathrm{~Gy}\end{array}$ & $\begin{array}{l}\text { Bronchial fistula related, } \\
7 \text { months after SABR }\end{array}$ \\
\hline \multirow[t]{4}{*}{ Milano et al. (35) } & $\begin{array}{l}49.5 \mathrm{~Gy} / 11 \mathrm{frx} \text { to one central } \\
\text { NSCLC followed by } 48 \mathrm{~Gy} / 4 \mathrm{frx} \\
15 \text { months later }\end{array}$ & Bronchus & $\begin{array}{l}\text { Bronchus received } 98 \mathrm{~Gy} \\
\text { cumulatively }\end{array}$ & $\begin{array}{l}\text { Hemoptysis } 6.5 \text { months after } \\
\text { second course of SABR }\end{array}$ \\
\hline & $\begin{array}{l}50 \mathrm{~Gy} / 10 \mathrm{frx} \text { to one central and } \\
\text { one peripheral NSCLC followed } \\
\text { by } 50 \mathrm{~Gy} / 10 \mathrm{frx} \text { to three new } \\
\text { central lesions and one bulky } \\
\text { recurrence of the previously } \\
\text { treated peripheral lesion } \\
11 \text { months later }\end{array}$ & Bronchus and trachea & Unknown & $\begin{array}{l}\text { Dyspnea } 2 \text { weeks after } \\
\text { second course of SABR }\end{array}$ \\
\hline & $\begin{array}{l}\text { 35-50 Gy/10 frx to five central } \\
\text { NSCLC }\end{array}$ & Bronchus and trachea & Unknown & $\begin{array}{l}\text { Bronchitis } 6 \text { months after } \\
\text { second course of SABR }\end{array}$ \\
\hline & $\begin{array}{l}35 \mathrm{~Gy} / 14 \mathrm{frx} \text { then } 18 \mathrm{~Gy} / 6 \mathrm{frx} \text { to } \\
\text { three central NSCLC and } \\
50 \mathrm{~Gy} / 10 \mathrm{frx} \text { to one peripheral } \\
\text { NSCLC }\end{array}$ & $\begin{array}{l}\text { Bronchus }(0.5 \mathrm{~cm} \text { from } \\
\text { tumor) and trachea }(1 \mathrm{~cm} \\
\text { from tumor) }\end{array}$ & Unknown & Dyspnea 4 months after SABR \\
\hline
\end{tabular}

${ }^{a}$ After previous intra-tracheobronchial brachytherapy to bilateral hilar lesions and SABR to the apical area of the same lobe.

volume encompassing effect associated with the relatively slower speed of a PET scan (Table 5). The inhalation and exhalation breath hold CTs have been used to estimate the extremes of breathing motion. Respiration monitoring may be used in this setting to confirm that the breathing range is constant and the ITV generated adequately encompasses the tumor at the time of actual treatment. Both methods provide less detail on tumor motion than 4D CT. As shown in Table 5, 4D CT was used for motion management in 7/14 studies in which motion encompassing techniques were used (19, $23,25,29,30,32,36)$. It can estimate the mean tumor position and the range of tumor motion in relation to adjacent normal thoracic organs with increased sophistication when compared to the other two approaches, which is critical for target volume delineation in central locations of the thorax. The use of 4D CT in the treatment planning of lung SABR has been described in detail by Slotman et al. (40). As shown by Wang et al., 4D CT based target volume delineation consistently resulted in smaller PTV volume in lung SABR, which may potentially lead to an increase in normal tissue sparing (41).
Other respiratory motion management techniques are also used in the treatment of central lung tumors with SABR. The breath hold technique has been used by Song et al. and Milano et al. in the delivery of SABR, while respiratory gating has been used by Song et al. and Oshiro et al. in their patients $(18,33,35)$. Forced shallow breathing with abdominal compression has been commonly used to reduce respiratory motion in the pre-4D CT era, when SABR began to become a treatment option for early stage NSCLC $(14,39,42)$. Both deep inspiration breath hold (DIBH) and end expiratory breath hold (EEBH) can be used for the breath hold technique while the DIBH approach can potentially improve the sparing of the normal lung tissue $(35,38)$. However, breath holding requires a high degree of patient cooperation and is often limited to the delivery of 3D-CRT and step-and-shoot IMRT due to the short duration of breath holding of $\leq 30 \mathrm{~s}$.

Respiratory gating refers to the delivery of radiation within a particular portion of a patient's respiratory cycle. The respiratory cycle can be monitored through external respiratory signal or internal fiducial markers, while the gating criteria can be set 
Table 4 | Studies on lung SABR reporting no severe toxicity associated with central location.

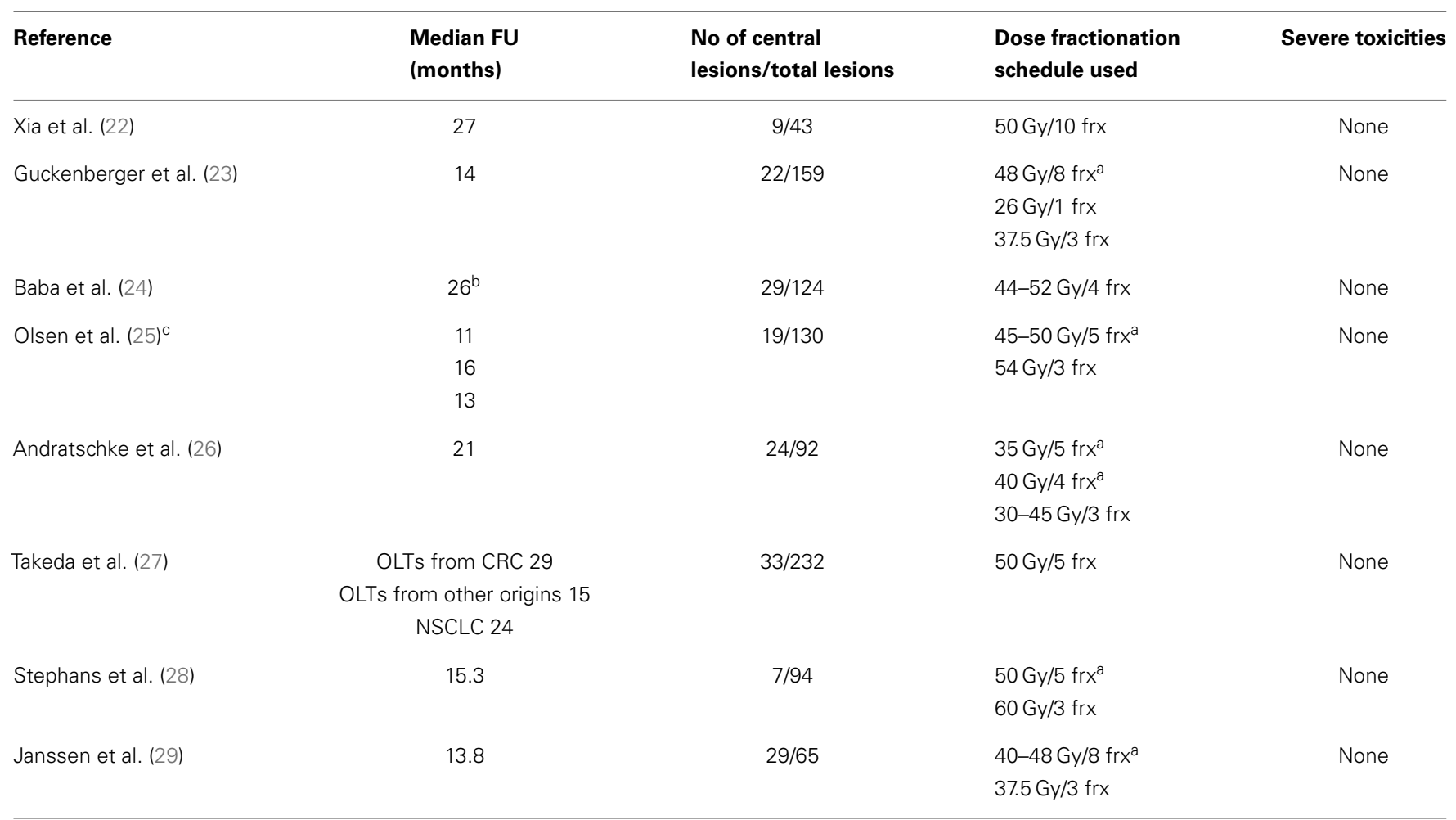

${ }^{a}$ Dose fractionation schedule for central lesions.

${ }^{b}$ For living patients only.

${ }^{c}$ Median FU based on dose fractionation schedule used.

OLTs, oligometastases; frx, fractions.

by either displacement (33), or phase based on a certain pre-set displacement distance or phase window, respectively. This technique requires respiration to be continuously monitored using surrogate markers of breathing motion $(18,33,43)$. Although it can potentially spare more normal tissue compared to the motion encompassing method, it requires a high degree of quality assurance to validate the accurate representation of tumor motion by the external signal and the internal fiducial markers (38). In addition, treatment time is increased with gating as radiation is only delivered when the target is in the gated window.

Real time tumor tracking is different from the other techniques of respiratory motion management in that the radiation beam moves in synchrony with the tumor as the patient is breathing. The use of this technique is commonly observed with lung SABR delivery by the CyberKnife (CK, Accuray Corp.), a device that attaches a linear accelerator to a robotic arm to allow for beam adaptation to full three-dimensional motion of the tumor under close image guidance $(31,34)$. This is achieved through the intermittent monitoring of internal fiducial markers or the tumor itself, coupled with the continuous monitoring of external respiratory markers (44). Although the treated volume can potentially be reduced with this highly automated approach, the treatment time is usually long (60-90 $\mathrm{min}$ ), and the localization of centrally located lung tumors on in-room x-rays may be difficult without the use of internal fiducial markers (44).

\section{IMAGE GUIDANCE IN THE DELIVERY OF LUNG SABR}

Regardless of the motion management strategy used, image guidance during daily treatment is essential in ensuring the accurate localization of the target volume in relation to adjacent normal structures. This allows for smaller PTV margins to be used, especially for centrally located lung tumors, with optimal dose volume coverage and OAR sparing. Image guidance strategies are onboard, peripheral, or integrated on various treatment delivery systems (1). Despite the ability to achieve very sharp dose gradient for normal structure sparing in SABR for central lung lesions, the clinical use of helical tomotherapy (a image-guided IMRT delivery system integrating a six MV linear accelerator with a helical CT) for this purpose has not be extensively reported (12). However, the first two strategies are widely adopted in SABR delivery.

On-board image guidance is conducted when the imaging device is attached to the actual treatment delivery system. The most commonly used on-board imaging device for the delivery of lung SABR is the cone beam CT (CBCT), which is re-constructed from a series of $\mathrm{x}$-ray projections obtained in a single rotation of the source and detector around the patient (45). In the most commonly available CBCT systems, the imaging axis is chosen to be $90^{\circ}$ to the treatment beam. CBCT provides $3 \mathrm{D}$ information of the tumor in relation to the critical normal structures for online verification of tumor localization prior to the delivery of daily treatment. It can be obtained with either MV or KV imaging. KV 
Table 5 | Treatment planning, immobilization, and image guidance in SABR for central lung tumors.

\begin{tabular}{|c|c|c|c|c|c|c|c|}
\hline Reference & $\begin{array}{l}\text { Respiratory } \\
\text { motion } \\
\text { management }\end{array}$ & ITV & $\begin{array}{l}\text { FDG PET } \\
\text { for target } \\
\text { definition }\end{array}$ & Dose calculation/TPS & Technique & Immobilization & Image guidance \\
\hline Haasbeek et al. (30) & e & Y & & -/BrainLab & $3 D$ & - & ExacTrac system \\
\hline Nuyttens et al. (31) & RTT & & & -/CyberKnife & IMRT & - & $\begin{array}{l}\text { Fiducial marker tracking per CyberKnife } \\
\text { system }\end{array}$ \\
\hline Rowe et al. (32) & e & Y & & $\mathrm{AAA} /-$ & 3D, IMRT & Full length vacuum cushion & СВCT \\
\hline Oshiro et al. (33) & c & & & -/Eclipse (Varian) & $3 D$ & Individualized body casts & Gated KV-radiographs \\
\hline Unger et al. (34) & RTT & & & $\begin{array}{l}\text { Non-isocentric inverse planning } \\
\text { algorithm with heterogeneity } \\
\text { correction/CyberKnife }\end{array}$ & IMRT & - & $\begin{array}{l}\text { IR emitting external markers and } \\
\text { internal fiducial markers used for real } \\
\text { time tumor tracking with CyberKnife }\end{array}$ \\
\hline Milano et al. (35) & $d$ & Y & Y & -/BrainLab & Arcs & - & ExacTrac system \\
\hline Chang et al. (36) & e & Y & & $-1-$ & $3 D$ & - & $\begin{array}{l}\text { CT-on-rail with orthogonal radiographs } \\
\text { to confirm isocenter }\end{array}$ \\
\hline Fakiris et al. (14) & a & Y & & $-1-$ & $3 D$ & $\begin{array}{l}\text { SBF with abdominal } \\
\text { compression }\end{array}$ & $\begin{array}{l}\text { Daily treatment guided by external } \\
\text { markers on SBF }\end{array}$ \\
\hline Onimaru et al. (17) & $\mathrm{b}$ & Y & & 3D RTP with heterogeneity correction & $3 \mathrm{D}$ & No immobilization cradles & Orthogonal radiographs on the first day \\
\hline Song et al. (18) & $a, c, d$ & Y & & $\begin{array}{l}\text {-/Render 3D system (Elekta) or } \\
\text { Eclipse (Varian) }\end{array}$ & - & Vacuum fitted SBF & $\mathrm{CBCT}$ \\
\hline Stauder et al. (19) & e & Y & Y & -/Eclipse (Varian) & $3 \mathrm{D}$ & BodyFix vacuum system & $\mathrm{CBCT}$ \\
\hline Peulen et al. (20) & a & Y & & $\begin{array}{l}\text { Pencil beam algorithm with } \\
\text { heterogeneity correction/- }\end{array}$ & $3 \mathrm{D}$ & $\begin{array}{l}\text { SBF with abdominal } \\
\text { compression }\end{array}$ & $\mathrm{CT}$ prior to each treatment \\
\hline Bral et al. (21) & $b, c$ & Y & Y & -/BrainLab & $3 \mathrm{D}$ & $\begin{array}{l}\text { Low density cradle with IR } \\
\text { skin markers on the thorax }\end{array}$ & $\begin{array}{l}\text { ExacTrac-like system using both } \\
\text { external and internal markers }\end{array}$ \\
\hline Xia et al. (22) & $f$ & Y & $\begin{array}{l}\text { N1 LN } \\
\text { delineation }\end{array}$ & Body gamma knife planning system & $\begin{array}{l}\text { MLC based } \\
\text { gamma knife }\end{array}$ & $\begin{array}{l}\text { Vacuum bag from head to } \\
\text { pelvis }\end{array}$ & - \\
\hline Guckenberger et al. (23) & e & Y & & Collapsed cone algorithm/- & $3 \mathrm{D}$ & SBF or BodyFix systems & $\mathrm{CT}$, in-room CT, then CBCT since 2005 \\
\hline Baba et al. (24) & $\mathrm{b}$ & Y & & ? AAA/eclipse (Varian) & $3 \mathrm{D}$ & BodyFix system & - \\
\hline Olsen et al. (25) & e & Y & & $\begin{array}{l}\text { Superposition convolution algorithm } \\
\text { with heterogeneity correction/- }\end{array}$ & $3 \mathrm{D}$ & SBF system or alpha cradle & $\mathrm{CBCT}$ \\
\hline Andratschke et al. (26) & $f$ & Y & & $\begin{array}{l}\text { Unknown algorithm with } \\
\text { heterogeneity correction/- }\end{array}$ & 3D/arcs & $\begin{array}{l}\text { Vacuum couch and low } \\
\text { pressure foil }\end{array}$ & $\begin{array}{l}\text { CT prior to each treatment, then CBCT } \\
\text { since } 2008\end{array}$ \\
\hline
\end{tabular}




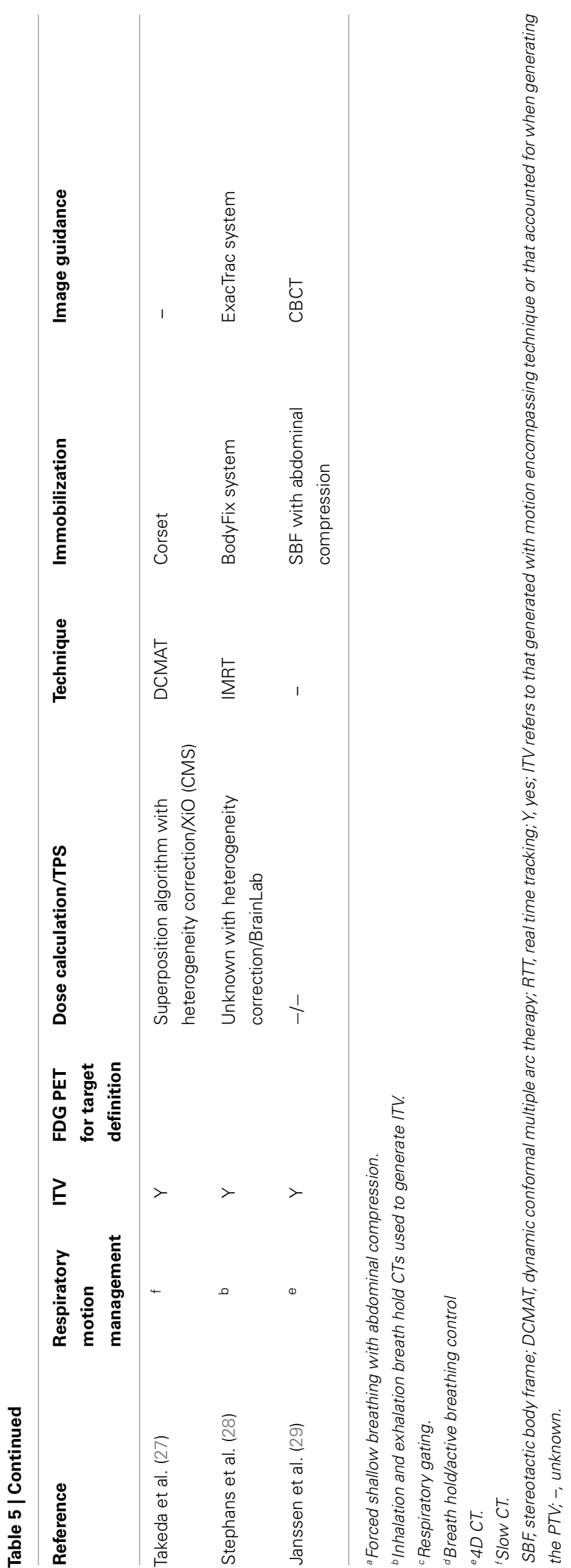

imaging is superior to MV imaging in providing better soft tissue resolution with low to moderate imaging doses, which potentially improves patient set up accuracy and alignment of tumor target volume in relation to adjacent critical structures (46). This may be especially helpful in the treatment of central lung lesions with SABR, as a high degree of anatomical information is necessary for the most optimal tumor localization. However, KV CBCT requires regular quality assurance for the alignment of the imaging and treatment beams (46).

Both 2D and 3D imaging are used in peripheral in-room image guidance strategies. The advantage of using imaging devices not directly attached to the treatment delivery system is that respiratory motion may be monitored during the delivery of radiation. However, they need to be carefully calibrated with the treatment beam's isocenter to minimize additional geometric uncertainties (1). CT-on-rails/in-room CT has been used for online image guidance with the treatment table moved to the imaging position after the patient is set up on the treatment table. Diagnostic quality CT images can be obtained with this approach for the best resolution of soft tissue structures prior to each treatment. However, additional set up errors may be introduced during patient movement between the imaging and treatment positions (46). Both CBCT and CT-on-rails/in-room CT have been used in image-guided SABR for central lung lesions. These strategies are frequently used with the motion encompassing method of respiratory motion management with low incidence of severe toxicities in the setting of primary irradiation, and tumor not directly involving the normal critical structure at risk $(18,19,22,23,25-27,29,32,36)$. As shown by Grills et al., small PTV margin accounting for systemic and random error may be consistently maintained when CBCT in conjunction with appropriate immobilization were used during SABR delivery for early stage NSCLC (47). In this study, the PTV margin may be reduced to $<5 \mathrm{~mm}$ with the patient in a stereotactic body frame and to $\sim 5 \mathrm{~mm}$ with a regular alpha cradle. Their findings were corroborated in a study by Guckenberger et al., which showed that the PTV margin can be reduced from 12 to $<5 \mathrm{~mm}$ when KV CBCT is used in addition to a stereotactic body frame (48). In another study, the mean lung dose and the $\mathrm{V}_{20}$ (volume of the normal lung receiving $20 \mathrm{~Gy}$ ) were reduced by $47-77.3 \%$; while the spinal cord dose was reduced by $55.2-$ $58.5 \%$ for central lung lesions when СВCT image guidance was used with active breathing control (a breath hold technique) in the delivery of lung SABR as a result of reduction in treatment set up margins enabled by combining image guidance and respiratory motion management (49). In this study, pre-correction set up margins of $14.1 \mathrm{~mm}$ in the cranial-caudal direction was able to be reduced to $4.7 \mathrm{~mm}$, while pre-correction set up margins of $\sim 10 \mathrm{~mm}$ in the left-right and anterior-posterior directions were reduced to 3.2 and $3.5 \mathrm{~mm}$, respectively. More recently, $4 \mathrm{D}$ CBCT has been under investigation to better capture tumor motion at the time of treatment, which may allow for small PTV margins of within $3 \mathrm{~mm}$ (50-52). Although fairly accurate with respiratory motion of $<5 \mathrm{~mm}$, 3D CBCT was shown to be less accurate in capturing respiratory motion than $4 \mathrm{D} \mathrm{CBCT}$ as motion artifacts increase with increased tumor motion $(53,54)$. In addition, accurate localization of the target volume during daily treatment may provide information for adaptive adjustment of the PTV margin 
and adaptive planning daily. Further exploration in this area is definitely warranted.

Commonly used 2D-imaging based peripheral strategies, such as the Novalis ExacTrac and Synchrony for CK, usually monitor external markers of respiration continuously with periodical verification of tumor location through $\mathrm{x}$-rays of internal tumor markers. With the Novalis ExacTrac system, respiratory motion can be captured by continuous monitoring of infra-red (IR) reflecting markers attached to the patient's abdomen, while $\mathrm{KV} \mathrm{x}$-rays can be matched to digitally re-constructed radiographs for localization verification of internal tumor markers $(43,54)$. This system can be used for respiratory gating, which may potentially limit the amount of normal tissue irradiated as the gating window can be limited to as small as $2 \mathrm{~mm}(43)$. When used to delivery SABR for central lung tumors $(21,28,30,35)$, low incidence of severe toxicities have been observed when re-irradiation was excluded in general $(14,17-21,30,32-35)$. However, Grade 5 toxicities related or potentially related to SABR for lesions in close proximity to the major airway and the heart were reported with this approach of image guidance $(21,30)$. This suggests that online correction with 3D imaging may be beneficial in certain situations due to the increased amount of 3D geometric detail of critical normal structures in relation to the PTV it provides to avoid non-intended inclusion of critical structures in the high dose volume.

Real time tumor tracking of the CK system is accomplished in a way that is very similar to the ExacTrac system $(43,44)$. With the Synchrony system, the internal and external marker motions appear to be highly correlated (55). However, external marker based tumor motion prediction are influenced by multiple factors, and its correlation with tumor motion may deteriorate with prolonged treatment duration (56). In addition, a high rate of pneumothorax has been observed after thoracic fiducial marker placement with frequent marker migration $(57,58)$. Clinically, CK-based SABR has been correlated with excellent clinical outcome (59). It was used to deliver SABR for central lung tumors with only one Grade 5 toxicity encountered when an endobronchial lesion in the mainstem bronchus was treated to the prescribed dose among a total of 76 patients reported in two studies $(31,34)$. The safe delivery of SABR with CK for central lesions, and especially hilar lesions with relative low incidence of severe toxicity may be due to the fact that relatively smaller PTV can be used with real time tumor tracking as no ITV is needed in this situation $(60,61)$. When compared with linac-based systems, CK may also be associated with improvement in the sparing of the normal lungs from low dose irradiation for anteriorly located tumors $(60,61)$. This location-based difference was mostly due to the system's inability to deliver radiation from underneath the patient. However, these findings suggest that it may provide an advantage in the delivery of SABR for relatively more anterior central lung tumors.

\section{CONCLUSION AND FUTURE DIRECTIONS}

As shown above, image guidance techniques integrated with respiratory motion management enhances tumor localization in the delivery of SABR for central lung tumors, which are mobile as a result of respiration. As result, very small PTV margin can be safely used to achieve optimal dose coverage of the tumor target and sparing of the adjacent critical normal structures. This makes SABR for central lung lesions feasible when the following criteria are met: primary irradiation of a limited number of lung lesions; dose constraints of the critical structures are strictly respected; and no direct overlap between the PTV and any immediately adjacent OARs. Therefore, the integration of respiratory motion management and image guidance is warranted in future clinical trials on SABR for centrally located lung tumors.

Particle therapy, such as proton therapy, has been increasingly investigated and utilized for the treatment of lung cancer in recent years due to the finite range of charged particles, which may provide an advantage over photon therapy in normal tissue sparing (62). Clinical experience in the delivery of stereotactic body proton therapy has been excellent without any severe toxicity reported in the treatment of central lesions $(63,64)$. Large smearing margins may be necessary to achieve the most optimal dose distribution in the delivery of passively scattered beams (PT), which may impair OAR sparing in situations of complex geometry (65). Active spot scanning, or intensity modulated proton therapy (IMPT) has been shown to provide a dosimetric advantage in the treatment of central lung lesions over PT and photon therapy $(66,67)$. However, dose distribution in IMPT is very sensitive to beam and tumor motion, as well as set up uncertainties. Methods to minimize interplay uncertainties have been proposed, which warrants further investigation in the future $(65,68,69)$.

\section{REFERENCES}

1. Verellen D, De Ridder M, Linthout N, Tournel K, Soete G, Storme G. Innovations in image-guided radiotherapy. Nat Rev Cancer (2007) 7:949-60. doi:10.1038/ nrc2288

2. van Herk M. Different styles of image-guided radiotherapy. Semin Radiat Oncol (2007) 17:258-67. doi:10.1016/j.semradonc.2007.07.003

3. Fowler JF, Tomé WA, Fenwick JD, Mehta MP. A challenge to traditional radiation oncology. Int J Radiat Oncol Biol Phys (2004) 60:1241-56. doi:10.1016/j.ijrobp. 2004.07.691

4. Seppenwoolde Y, Shirato H, Kitamura K, Shimizu S, van Herk M, Lebesque JV, et al. Precise and real-time measurement of 3D tumor motion in lung due to breathing and heartbeat, measured during radiotherapy. Int J Radiat Oncol Biol Phys (2002) 53:822-34. doi:10.1016/S0360-3016(02)02803-1

5. van Herk M, Remeijer P, Rasch C, Lebesque JV. The probability of correct target dosage: dose-population histograms for deriving treatment margins in radiotherapy. Int J Radiat Oncol Biol Phys (2000) 47:1121-35. doi:10.1016/S03603016(00)00518-6

6. Mageras GS, Pevsner A, Yorke ED, Rosenzweig KE, Ford EC, Hertanto A, et al. Measurement of lung tumor motion using respiration-correlated CT. Int J Radiat Oncol Biol Phys (2004) 60:933-41. doi:10.1016/S0360-3016(04)01078-8

7. Redmond KJ, Song DY, Fox JL, Zhou J, Rosenzweig CN, Ford E. Respiratory motion changes of lung tumors over the course of radiation therapy based on respiration-correlated four-dimensional computed tomography scans. Int J Radiat Oncol Biol Phys (2009) 75:1605-12. doi:10.1016/j.ijrobp.2009.05.024

8. Balter JM, Kessler ML. Imaging and alignment for image-guided radiation therapy. J Clin Oncol (2007) 8:931-7. doi:10.1200/JCO.2006.09.7998

9. Chi A, Liao Z, Nguyen NP, Xu J, Stea B, Komaki R. Systemic review of the patterns of failure following stereotactic body radiation therapy in early-stage nonsmall-cell lung cancer: clinical implications. Radiother Oncol (2010) 94:1-11. doi:10.1016/j.radonc.2009.12.008

10. Ricardi U, Filippi AR, Guarneri A, Ragona R, Mantovani C, Giglioli F, et al. Stereotactic body radiation therapy for lung metastases. Lung Cancer (2012) 75:77-81. doi:10.1016/j.lungcan.2011.04.021

11. Baschnagel AM, Mangona VS, Robertson JM, Welsh RJ, Kestin LL, Grills IS. Lung metastases treated with image-guided stereotactic body radiation therapy. Clin Oncol (2013) 25:236-41. doi:10.1016/j.clon.2012.12.005 
12. Chi A, Jang SY, Welsh JS, Nguyen NP, Ong E, Gobar L, et al. Feasibility of helical tomotherapy in stereotactic body radiation therapy for centrally located early stage non-small-cell lung cancer or lung metastases. Int J Radiat Oncol Biol Phys (2011) 81:856-62. doi:10.1016/j.ijrobp.2010.11.051

13. Timmerman R, McGarry R, Yiannoutsos C, Papiez L, Tudor K, DeLuca J, et al. Excessive toxicity when treating central tumors in a phase II study of stereotactic body radiation therapy for medically inoperable early-stage lung cancer. J Clin Oncol (2006) 24:4833-9. doi:10.1200/JCO.2006.07.5937

14. Fakiris AJ, McGarry RC, Yiannoutsos CT, Papiez L, Williams M, Henderson MA, et al. Stereotactic body radiation therapy for early-stage non-small-cell lung carcinoma: four-year results of a prospective phase II study. Int J Radiat Oncol Biol Phys (2009) 75:677-82. doi:10.1016/j.ijrobp.2008.11.042

15. Corradetti MN, Haas AR, Rengan R. Central-airway necrosis after stereotactic body-radiation therapy. N Engl J Med (2012) 366:2327-9. doi:10.1056/ NEJMc1203770

16. Nagata Y, Wulf J, Lax I, Timmerman R, Zimmermann F, Stojkovski I, et al. Stereotactic radiotherapy of primary lung cancer and other targets: results of consultant meeting of the international atomic energy agency. Int J Radiat Oncol Biol Phys (2011) 79:660-9. doi:10.1016/j.ijrobp.2010.10.004

17. Onimaru R, Shirato H, Shimizu S, Kitamura K, Xu B, Fukumoto S, et al. Tolerance of organs at risk in small-volume, hypofractionated, image-guided radiotherapy for primary and metastatic lung cancers. Int J Radiat Oncol Biol Phys (2003) 56:126-35. doi:10.1016/S0360-3016(03)00095-6

18. Song SY, Choi W, Shin SS, Lee SW, Ahn SD, Kim JH, et al. Fractionated stereotactic body radiation therapy for medically inoperable stage I lung cancer adjacent to central large bronchus. Lung Cancer (2009) 66:89-93. doi:10.1016/j.lungcan. 2008.12.016

19. Stauder MC, Macdonald OK, Olivier KR, Call JA, Lafata K, Mayo CS, et al. Early pulmonary toxicity following lung stereotactic body radiation therapy delivered in consecutive daily fractions. Radiother Oncol (2011) 99:166-71. doi:10.1016/j.radonc.2011.04.002

20. Peulen H, Karlsson K, Lindberg K, Tullgren O, Baumann P, Lax I, et al. Toxicity after reirradiation of pulmonary tumours with stereotactic body radiotherapy. Radiother Oncol (2011) 101:260-6. doi:10.1016/j.radonc.2011.09. 012

21. Bral S, Gevaert T, Linthout N, Versmessen H, Collen C, Engels B, et al. Prospective, risk-adapted strategy of stereotactic body radiotherapy for early-stage nonsmall-cell lung cancer: results of a phase II trial. Int J Radiat Oncol Biol Phys (2011) 80:1343-9. doi:10.1016/j.ijrobp.2010.04.056

22. Xia T, Li H, Sun Q, Wang Y, Fan N, Yu Y, et al. Promising clinical outcome of stereotactic body radiation therapy for patients with inoperable stage I/II non-small-cell lung cancer. Int J Radiat Oncol Biol Phys (2006) 66:117-25. doi:10.1016/j.ijrobp.2006.04.013

23. Guckenberger M, Wulf J, Mueller G, Krieger T, Baier K, Gabor M, et al. Doseresponse relationship for image-guided stereotactic body radiotherapy of pulmonary tumors: relevance of 4D dose calculation. Int J Radiat Oncol Biol Phys (2009) 74:47-54. doi:10.1016/j.ijrobp.2008.06.1939

24. Baba F, Shibamoto Y, Ogino H, Murata R, Sugie C, Iwata H, et al. Clinical outcomes of stereotactic body radiotherapy for stage I non-small cell lung cancer using different doses depending on tumor size. Radiat Oncol (2010) 5:81. doi:10.1186/1748-717X-5-81

25. Olsen JR, Robinson CG, El Naqa I, Creach KM, Drzymala RE, Bloch C, et al. Dose-response for stereotactic body radiotherapy in early-stage nonsmall-cell lung cancer. Int J Radiat Oncol Biol Phys (2011) 81:e299-303. doi:10.1016/j.ijrobp.2011.01.038

26. Andratschke N, Zimmermann F, Boehm E, Schill S, Schoenknecht C, Thamm R, et al. Stereotactic radiotherapy of histologically proven inoperable stage I nonsmall cell lung cancer: patterns of failure. Radiother Oncol (2011) 101:245-9. doi:10.1016/j.radonc.2011.06.009

27. Takeda A, Kunieda E, Ohashi T, Aoki Y, Koike N, Takeda T. Stereotactic body radiotherapy (SBRT) for oligometastatic lung tumors from colorectal cancer and other primary cancers in comparison with primary lung cancer. Radiother Oncol (2011) 101:255-9. doi:10.1016/j.radonc.2011.05.033

28. Stephans KL, Djemil T, Reddy CA, Gajdos SM, Kolar M, Mason D, et al. A comparison of two stereotactic body radiation fractionation schedules for medically inoperable stage I non-small cell lung cancer: the Cleveland clinic experience. J Thorac Oncol (2009) 4:976-82. doi:10.1097/JTO.0b013e3181adf509
29. Janssen S, Dickgreber NJ, Koenig C, Bremer M, Werner M, Karstens JH, et al. Image-guided hypofractionated small-volume radiotherapy of non-small cell lung cancer - feasibility and clinical outcome. Onkologie (2012) 35:408-12. doi:10.1159/000340064

30. Haasbeek CJ, Lagerwaard FJ, Slotman BJ, Senan S. Outcomes of stereotactic ablative radiotherapy for centrally located early-stage lung cancer. J Thorac Oncol (2011) 6:2036-43. doi:10.1097/JTO.0b013e31822e71d8

31. Nuyttens JJ, van der Voort van Zyp NC, Praag J, Aluwini S, van Klaveren RJ, Verhoef $\mathrm{C}$, et al. Outcome of four-dimensional stereotactic radiotherapy for centrally located lung tumors. Radiother Oncol (2012) 102:383-7. doi:10.1016/j.radonc.2011.12.023

32. Rowe BP, Boffa DJ, Wilson LD, Kim AW, Detterbeck FC, Decker RH. Stereotactic body radiotherapy for central lung tumors. J Thorac Oncol (2012) 7:1394-9. doi:10.1097/JTO.0b013e3182614bf3

33. Oshiro Y, Aruga T, Tsuboi K, Marino K, Hara R, Sanayama Y, et al. Stereotactic body radiotherapy for lung tumors at the pulmonary hilum. Strahlenther Onkol (2010) 186:274-9. doi:10.1007/s00066-010-2072-y

34. Unger K, Ju A, Oermann E, Suy S, Yu X, Vahdat S, et al. CyberKnife for hilar lung tumors: report of clinical response and toxicity. J Hematol Oncol (2010) 3:39. doi:10.1186/1756-8722-3-39

35. Milano MT, Chen Y, Katz AW, Philip A, Schell MC, Okunieff P. Central thoracic lesions treated with hypofractionated stereotactic body radiotherapy. Radiother Oncol (2009) 91:301-6. doi:10.1016/j.radonc.2009.03.005

36. Chang JY, Balter PA, Dong L, Yang Q, Liao Z, Jeter M, et al. Stereotactic body radiation therapy in centrally and superiorly located stage I or isolated recurrent non-small-cell lung cancer. Int J Radiat Oncol Biol Phys (2008) 72:967-71. doi:10.1016/j.ijrobp.2008.08.001

37. Grills IS, Hope AJ, Guckenberger M, Kestin LL, Werner-Wasik M, Sonke JJ, et al. A collaborative analysis of stereotactic lung radiotherapy outcomes for early-stage non-small-cell lung cancer using daily online cone-beam computed tomography image-guided radiotherapy. J Thorac Oncol (2012) 7:1382-93. doi:10.1097/JTO.0b013e318260e00d

38. Keall PJ, Mageras GS, Balter JM, Emery RS, Forster KM, Jiang SB, et al. The management of respiratory motion in radiation oncology report of AAPM Task Group 76. Med Phys (2006) 33:3874-900. doi:10.1118/1.2349696

39. Wulf J, Hadinger U, Oppitz U, Olshausen B, Flentje M. Stereotactic radiotherapy of extracranial targets: CT simulation and accuracy of treatment in the stereotactic body frame. Radiother Oncol (2000) 57:225-36. doi:10.1016/S0167-8140(00) 00226-7

40. Slotman BJ, Lagerwaard FJ, Senan S. 4D imaging for target definition in stereotactic radiotherapy for lung cancer. Acta Oncol (2006) 45:966-72. doi:10.1080/ 02841860600902817

41. Wang L, Hayes S, Paskalev K, Jin L, Buyyounouski MK, Ma CC, et al. Dosimetric comparison of stereotactic body radiotherapy using 4D CT and multiphase CT images for treatment planning of lung cancer: evaluation of the impact on daily dose coverage. Radiother Oncol (2009) 91:314-24. doi:10.1016/j.radonc.2008. 11.018

42. Timmerman R, Papiez L, McGarry R, Likes L, DesRosiers C, Frost S, et al. Extracranial stereotactic radioablation: results of a phase I study in medically inoperable stage I non-small cell lung cancer. Chest (2003) 124:1946-55. doi:10.1378/chest.124.5.1946

43. Verellen D, Depuydt T, Gevaert T, Linthout N, Tournel K, Duchateau M, et al. Gating and tracking, 4D in thoracic tumours. Cancer Radiother (2010) 14:446-54. doi:10.1016/j.canrad.2010.06.002

44. Gibbs IC, Loo BW Jr. CyberKnife stereotactic ablative radiotherapy for lung tumors. Technol Cancer Res Treat (2010) 9:589-96.

45. Dawson LA, Jaffray DA. Advances in image-guided radiation therapy. J Clin Oncol (2007) 25:938-46. doi:10.1200/JCO.2006.09.9515

46. Korreman S, Rasch C, McNair H, Verellen D, Oelfke U, Maingon P, et al. The European society of therapeutic radiology and oncology-European institute of radiotherapy (ESTRO-EIR) report on 3D CT-based in-room image guidance systems: a practical and technical review and guide. Radiother Oncol (2010) 94:129-44. doi:10.1016/j.radonc.2010.01.004

47. Grills IS, Hugo G, Kestin LL, Galerani AP, Chao KK, Wloch J, et al. Imageguided radiotherapy via daily online cone-beam CT substantially reduces margin requirements for stereotactic lung radiotherapy. Int J Radiat Oncol Biol Phys (2008) 70:1045-56. doi:10.1016/j.ijrobp.2007.07.2352 
48. Guckenberger M, Krieger T, Richter A, Baier K, Wilbert J, Sweeney RA, et al. Potential of image-guidance, gating and real-time tracking to improve accuracy in pulmonary stereotactic body radiotherapy. Radiother Oncol (2009) 91:288-95. doi:10.1016/j.radonc.2008.08.010

49. Shen Y, Zhang H, Wang J, Zhong R, Jiang X, Xu Q, et al. Hypofractionated radiotherapy for lung tumors with online cone beam CT guidance and active breathing control. Radiat Oncol (2010) 5:19. doi:10.1186/1748-717X-5-19

50. Purdie TG, Moseley DJ, Bissonnette JP, Sharpe MB, Franks K, Bezjak A, et al. Respiration correlated cone-beam computed tomography and 4DCT for evaluating target motion in stereotactic lung radiation therapy. Acta Oncol (2006) 45:915-22. doi:10.1080/02841860600907345

51. Sonke JJ, Lebesque J, van Herk M. Variability of four-dimensional computed tomography patient models. Int J Radiat Oncol Biol Phys (2008) 70:590-8. doi:10.1016/j.ijrobp.2007.08.067

52. Sonke JJ, Rossi M, Wolthaus J, van Herk M, Damen E, Belderbos J. Frameless stereotactic body radiotherapy for lung cancer using four-dimensional cone beam CT guidance. Int J Radiat Oncol Biol Phys (2009) 74:567-74. doi:10.1016/j.ijrobp.2008.08.004

53. Sweeney RA, Seubert B, Stark S, Homann V, Müller G, Flentje M, et al. Accuracy and inter-observer variability of $3 \mathrm{D}$ versus $4 \mathrm{D}$ cone-beam CT based imageguidance in SBRT for lung tumors. Radiat Oncol (2012) 7:81. doi:10.1186/1748717X-7-81

54. Jin JY, Yin FF, Tenn SE, Medin PM, Solberg TD. Use of the BrainLab ExacTrac X-Ray 6D system in image-guided radiotherapy. Med Dosim (2008) 33:124-34. doi:10.1016/j.meddos.2008.02.005

55. Hoogeman M, Prévost JB, Nuyttens J, Pöll J, Levendag P, Heijmen B. Clinical accuracy of the respiratory tumor tracking system of the CyberKnife: assessment by analysis of log files. Int J Radiat Oncol Biol Phys (2009) 74:297-303. doi:10.1016/j.ijrobp.2008.12.041

56. Malinowski KT, McAvoy TJ, George R, Dieterich S, D’Souza WD. Mitigating errors in external respiratory surrogate-based models of tumor position. Int J Radiat Oncol Biol Phys (2012) 82:e709-16. doi:10.1016/j.ijrobp.2011.05.042

57. Pennathur A, Luketich JD, Heron DE, Abbas G, Burton S, Chen M, et al. Stereotactic radiosurgery for the treatment of stage I non-small cell lung cancer in high-risk patients. J Thorac Cardiovasc Surg (2009) 137:597-604. doi:10.1016/j.jtcvs.2008.06.046

58. Bhagat N, Fidelman N, Durack JC, Collins J, Gordon RL, LaBerge JM, et al. Complications associated with the percutaneous insertion of fiducial markers in the thorax. Cardiovasc Intervent Radiol (2010) 33:1186-91. doi:10.1007/s00270010-9949-0

59. van der Voort van Zyp NC, Prévost JB, Hoogeman MS, Praag J, van der Holt B, Levendag PC, et al. Stereotactic radiotherapy with real-time tumor tracking for non-small cell lung cancer: clinical outcome. Radiother Oncol (2009) 91:296-300. doi:10.1016/j.radonc.2009.02.011

60. Atalar B, Aydin G, Gungor G, Caglar H, Yapici B, Ozyar E. Dosimetric comparison of robotic and conventional linac-based stereotactic lung irradiation in early-stage lung cancer. Technol Cancer Res Treat (2012) 11:249-55. doi: $10.7785 /$ tcrt.2012.500293

61. Ding C, Chang CH, Haslam J, Timmerman R, Solberg T. A dosimetric comparison of stereotactic body radiation therapy techniques for lung cancer: robotic versus conventional linac-based systems. J Appl Clin Med Phys (2010) 11:3223.
62. Liao Z, Lin SH, Cox JD. Status of particle therapy for lung cancer. Acta Oncol (2011) 50:745-56. doi:10.3109/0284186X.2011.590148

63. Hata M, Tokuuye K, Kagei K, Sugahara S, Nakayama H, Fukumitsu N, et al. Hypofractionated high-dose proton beam therapy for stage I non-small cell lung cancer: preliminary results of a phase I/II clinical study. Int J Radiat Oncol Biol Phys (2007) 68:786-93. doi:10.1016/j.ijrobp.2006.12.063

64. Fujii O, Demizu Y, Hashimoto N, Araya M, Takaqi M, Terashima K, et al. A retrospective comparison of proton therapy and carbon ion therapy for stage I non-small cell lung cancer. Radiother Oncol (2013) 109:32-7. doi:10.1016/j. radonc.2013.08.038

65. Kang Y, Zhang X, Chang JY, Wang H, Wei X, Liao Z, et al. 4D proton treatment planning strategy for mobile lung tumors. Int J Radiat Oncol Biol Phys (2007) 67:906-14. doi:10.1016/j.ijrobp.2006.10.045

66. Register SP, Zhang X, Mohan R, Chang JY. Proton stereotactic body radiation therapy for clinically challenging cases of centrally and superiorly located stage I non-small-cell lung cancer. Int J Radiat Oncol Biol Phys (2011) 80:1015-22. doi:10.1016/j.ijrobp.2010.03.012

67. Seco J, Gu G, Marcelos T, Kooy H, Willers $H$. Proton arc reduces range uncertainty effects and improves conformality compared with photon volumetric modulated arc therapy in stereotactic body radiation therapy for non-small cell lung cancer. Int J Radiat Oncol Biol Phys (2013) 87:188-94. doi:10.1016/j.ijrobp.2013.04.048

68. Seco J, Robertson D, Trofimov A, Paganetti H. Breathing interplay effects during proton beam scanning: simulation and statistical analysis. Phys Med Biol (2009) 54:N283-94. doi:10.1088/0031-9155/54/14/N01

69. Santiago A, Jelen U, Ammazzalorso F, Engenhart-Cabillic R, Fritz P, Mühlnickel $\mathrm{W}$, et al. Reproducibility of target coverage in stereotactic spot scanning proton lung irradiation under high frequency jet ventilation. Radiother Oncol (2013) 109:45-50. doi:10.1016/j.radonc.2013.09.013

Conflict of Interest Statement: The Guest Associate Editor, Ulf Karlsson, declares that, despite having collaborated with authors Alexander Chi and Nam Nguyen, the review process was handled objectively and no conflict of interest exists. The authors declare that the research was conducted in the absence of any commercial or financial relationships that could be construed as a potential conflict of interest.

Received: 02 January 2014; paper pending published: 30 January 2014; accepted: 30 May 2014; published online: 25 June 2014.

Citation: Chi A, Nguyen NP and Komaki R (2014) The potential role of respiratory motion management and image guidance in the reduction of severe toxicities following stereotactic ablative radiation therapy for patients with centrally located early stage non-small cell lung cancer or lung metastases. Front. Oncol. 4:151. doi: 10.3389/fonc.2014.00151

This article was submitted to Radiation Oncology, a section of the journal Frontiers in Oncology.

Copyright (C) 2014 Chi, Nguyen and Komaki. This is an open-access article distributed under the terms of the Creative Commons Attribution License (CC BY). The use, distribution or reproduction in other forums is permitted, provided the original author(s) or licensor are credited and that the original publication in this journal is cited, in accordance with accepted academic practice. No use, distribution or reproduction is permitted which does not comply with these terms. 